\title{
Lotus tenuis SEEDLING ESTABLISHMENT AND BIOMASS PRODUCTION IN FLOODING PAMPA GRASSLANDS (BUENOS AIRES, ARGENTINA)
}

\author{
Osvaldo R. Vignolio ${ }^{1 *}$, and Osvaldo N. Fernández ${ }^{1}$
}

\begin{abstract}
Biomass and plant density of Lotus tenuis Waldst. \& Kit. ex Willd. have been reported in decreasing in grasslands and pastures. Our objective was to determine if L. tenuis biomass and plant density can be increased in grassland through seed addition. Two separated experiments under cattle grazing exclusion were conducted in three paddocks of a Flooding Pampa grassland. The first experiment was from autumn 2004 to autumn 2006 and the second from autumn 2005 to autumn 2007. Different L. tenuis seed additions (0, 57, 229, 917 and 1833 seeds $\left.\mathrm{m}^{-2}\right)$ were broadcast into experimental plots. In the second experiment, besides seed additions there was a reseeding of approximately 900 seed $\mathrm{m}^{-2}$ from seed rain produced by plants of grassland. Seed density explained the $81 \%$ and $19 \%$ of the variation in seedling density and L. tenuis biomass, respectively. Seedling emergence occurred mainly between autumn and early spring, while seedling mortality was mainly between late spring and early summer. Lotus tenuis adult plant density and biomass production increased with seed additions. Total biomass production in the plant community varied between $589.94 \pm 26.89$ and $1042.44 \pm 54.39 \mathrm{~g} \mathrm{~m}^{-2} \mathrm{yr}^{-1}$ and the differences were principally attributed to precipitations. Lotus tenuis biomass contribution was of approximately $10 \%$. The results suggest that $L$. tenuis seedling and plant establishment and biomass production can be increased through seed addition and/or seed rain through grazing exclusion during reproductive period.
\end{abstract}

Key words: Legume, forage quality, population attributes, seedling mortality, seed addition.

\section{INTRODUCTION}

Flooding Pampa grasslands (Buenos Aires, Argentina) have limited amounts of native forage legumes and in their biomass contribution respect to the other species of plant communities. In the Flooding Pampa grasslands Lotus tenuis Waldst. \& Kit. ex Willd. is one of the most economically important exotic legumes. Lotus tenuis spread by seeds and its seedling establishment is facilitated by disturbance generated by fire, grazing and cattle dung (Sevilla et al., 1996; Laterra, 1997; Juan et al., 2000; Vignolio and Fernández 2010). This species fixes $\mathrm{N}$ via symbiosis, benefits the growth of grass through soil $\mathrm{N}$ availability, increases the primary productivity and forage quality, is consumed by cattle and can grow

${ }^{1}$ Unidad Integrada Balcarce (Universidad Nacional de Mar del Plata, Facultad de Ciencias Agrarias, Instituto Nacional de Tecnología Agropecuaria, Estación Experimental Agropecuaria Balcarce), CC 276, 7620 Balcarce, Argentina.

*Corresponding author (ovignolio@balcarce.inta.gov.ar).

Received: 14 June 2010.

Accepted: 11 October 2010. in soils where the low fertility and/or flooding conditions affect negatively the persistence of other forage legumes (Colabelli and Miñón, 1993; Colabelli and Viviani Rossi, 1997; Quinos et al., 1998; Refi and Escuder, 1998; Vignolio et al., 1999; Juan et al., 2000).

Defoliation has been reported to lower L. tenuis plant number and biomass production (Miñón and Refi, 1993; Colabelli and Miñón, 1994; Acuña and Cuevas, 1999). Lotus tenuis seedling recruitment can be increased by controlling grazing (Sevilla et al., 1996), but continuous and heavy grazing can negatively affect seed production and plant survival (Fernández et al., 2008; Vignolio et al., 2010). In different grasslands it has been documented that the persistence, recruitment of plant species and primary productivity can be limited by seed availability in the soil bank (Oersterheld and Sala, 1990; Tilman, 1997; Zobel et al., 2000; Lenz and Facelli, 2005; Martin and Wilsey, 2006; Thomsen et al., 2006). Under continuous grazing, the soil seed bank of the palatable species can be significantly reduced and affect the persistence of plant population (Sternberg et al., 2003). Seed limitation can be minimized through seed additions (Oersterheld and Sala, 
1990; Martin and Wilsey, 2006) and/or through grasslands management that allows natural reseeding (Bologna et al., 1996).

Our objective was to determinate if $L$. tenuis seedlings and plant establishment, and primary production in a Flooding Pampa grassland, can be increased through seed addition and natural reseeding. We measured these population plant attributes because they are key stages in the propagation and productivity of the species in the grasslands.

\section{MATERIALS AND METHODS}

\section{Study area}

The study was located in a grassland of the Flooding Pampa situated in San Marcos, Ayacucho (37 $39^{\circ} \mathrm{S}, 58^{\circ} 29^{\prime}$ W) Buenos Aires Province, Argentina. Grassland was used for extensive beef cattle breeding with a continuous stocking rate of $0.7 \mathrm{AU} \mathrm{ha}^{-1}$. The primary productivity is maximum during spring-summer and minimum in winter. The Flooding Pampa grasslands climate is temperate, subhumid, usually affected by floods in winter and spring and drought in summer. Annual precipitation average is approximately $950 \mathrm{~mm}$.

\section{Experimental layout}

Three paddocks of $35 \times 35 \mathrm{~m}$ were selected in the grassland. Each paddock was wire fenced to exclude cattle grazing during the experimental period. Plant community of the paddock was composed principally by short monocots (grasses, sedges and rushes): Agropyron sp., Carex spp., Cynodon dactylon (L.) Pers., Cyperus spp., Distichlis spicata (L.) Greene, Juncus spp., Paspalum dilatatum Poir., Paspalum vaginatum Sw., Sporobolus indicus (L.) R. Br., Stenotaphrum secundatum (Walter) Kuntze, Jarava plumosa (Spreng.) S.W.L. Jacobs and J. Everett. Non-legume dicots: Ambrosia tenuifolia Spreng., Aster scuamatus Symphyotrichum subulatum (Michx.) G.

L. Nesom, Plantago lanceolata L. and Setaria parviflora (Poir.) Kerguélen. Legume dicots: Adesmia bicolor (Poir.) DC., Lotus tenuis and Trifolium repens L. Soil test was done in each paddock (Table 1).
In each paddock, two separated experiments were conducted. The first experiment was from March 2004 to April 2006 on 15 plots and the second one from April 2005 to April 2007 on other 15 different plots (Table 2). Permanent 15 fixed plots $(1.50 \times 1.50 \mathrm{~m})$ were arranged in each paddock in a completely randomized design, with three replications for each five seed additions. The distance among plots was $50 \mathrm{~cm}$. Lotus tenuis seeds (cv. INTA Pampa) were used. Seeds were scarified with sand paper to break physical dormancy and inoculated with Rhizobium loti and germination percentage was determined. Seed number in conditions of germination was: 0 (control); 57; 229; 917; 1833 seeds $\mathrm{m}^{-2}$ for $1^{\text {st }}, 2^{\text {sd }}$, $3^{\text {rd }}, 4^{\text {th }}$ and $5^{\text {th }}$ seed addition, respectively. Soil seed bank recorded in this same grassland, near of experimental paddock under continuous stocking was approximately 50 seeds $\mathrm{m}^{-2}$ (Fernández et al., 2008).

Lotus tenuis was sowed in early autumn because its recruitment is suitable due to warm climate and precipitations (Table 2). Due to slow rate of L. tenuis seedling growth, in both experiments, one day before of seed additions, plant communities of the paddocks were mechanically mowing at $4 \mathrm{~cm}$ height with bar of 0.50 $\mathrm{m}$ width. This disturbance to reduce plant competition, provide gaps and obtain uniform seedling establishment. Plant biomass was hand removed after mowing. On 23 March 2004 L. tenuis seeds were hand-sowed onto plots (depth of $0 \mathrm{~mm}$ ) (Table 2).

\section{First experimental period}

Lotus tenuis seedling density. Seedling density was recorded in each period during autumn, winter, spring and summer (Table 2). Plots were divided into nine subplots of $0.5 \times 0.5 \mathrm{~m}$ each one, and seedling numbers were determined in sixteen $100 \mathrm{~cm}^{2}$ quadrants placed at fixed locations (Figure 1). Seedling mortality was considered like reduction in seedling number from measurement to measurement.

Biomass production. Aerial biomass production of plant communities was determined through standing crop harvest. Biomass was hand harvested at $4 \mathrm{~cm}$ high in same

Table 1. Soil test of the upper $15 \mathrm{~cm}$ (mean \pm SE) analysis of pH, electrical conductivity (EC), phosphorus (P; Bray 1 method), organic matter (OM, Walkley and Black method) and interchange Na in the experimental paddocks of a Flooding Pampa grassland.

\begin{tabular}{|c|c|c|c|c|c|}
\hline Paddock & pH & EC & $\mathbf{P}$ & OM & $\mathrm{Na}$ \\
\hline & soil: $\mathrm{H}_{2} \mathrm{O}, 1: 2.5$ & mmohs $\mathrm{cm}^{-1}$ & $\mathrm{mg} \mathrm{kg}^{-1}$ & $\%$ & $\mathrm{cmol}_{\mathrm{c}} 100 \mathrm{~g}^{-1}$ \\
\hline 1 & $8.17 \pm 0.56$ & $2.02 \pm 0.42$ & $5.60 \pm 0.38$ & $5.15 \pm 1.15$ & $9.17 \pm 1.51$ \\
\hline 2 & $9.20 \pm 0.23$ & $2.67 \pm 0.54$ & $6.77 \pm 0.21$ & $3.70 \pm 0.75$ & $10.70 \pm 1.30$ \\
\hline 3 & $9.45 \pm 0.20$ & $2.17 \pm 0.47$ & $7.25 \pm 0.60$ & $4.05 \pm 0.93$ & $14.72 \pm 1.87$ \\
\hline Probability & 0.083 & 0.62 & 0.06 & 0.56 & 0.08 \\
\hline
\end{tabular}


Table 2. Grassland operations and data collection during the first and the second experiment at Flooding Pampa.

\begin{tabular}{llll}
\hline First experiment & \multicolumn{1}{c}{ Date } & Second experiment & Date \\
\hline Seed addition & 23 March 2004 & & \\
SR 1 & 24 May 2004 & & \\
SR 2 & 1 July 2004 & & \\
SR 3 & 27 September 2004 & & \\
SR 4 & 22 December 2004 & & \\
BH 1 $>$ Seed rain & 30 December 2004 & & \\
BH 2 & 31 March 2005 & Seed addition & 19 April 2005 \\
& & SR 1 & 23 June 2005 \\
& & SR 2 & WD \\
& & SR 3 & 13 September 2005 \\
& & SR 4 & 17 November 2005 \\
& & BH 1 & 30 November 2005 \\
BH 3 & & \\
BH 4 & 1 December 2005 & BH 2 & 11 April 2006 \\
& 25 April 2005 & BH 3 & 15 December 2006 \\
& & BH 4 & 13 April 2007 \\
\hline
\end{tabular}

References: Brace indicates the period of Lotus tenuis seed rain during summer 2005 and increasing the soil seed bank during second experimental period; $\mathrm{BH}$ : biomass harvest; SR: seedling record; WD: without data.

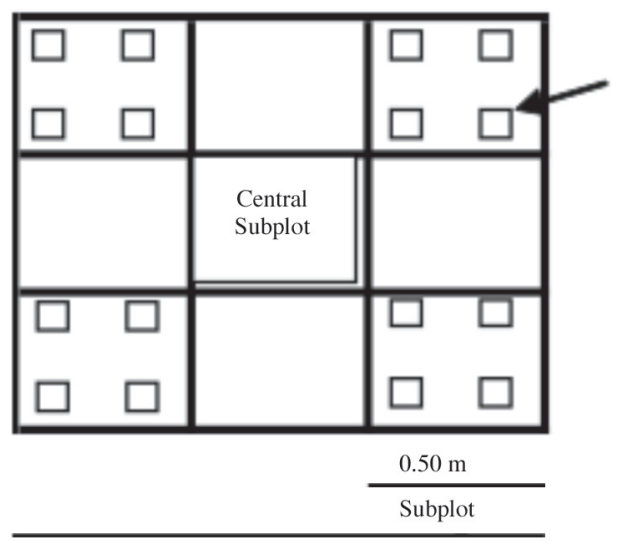

Plot $(1.50 \mathrm{~m})$

Figure 1. Experimental plot and central subplot. The arrow indicates one of the 16 quadrants of $100 \mathrm{~cm}^{2}$ where Lotus tenuis seedling were recorded. Harvest of aerial biomass production of plant community and the number of $L$. tenuis adult plants were determined in the central subplot.

central subplot $(0.5 \times 0.5 \mathrm{~m})$ of each plot (Figure 1$)$. Four harvests were realized between December 2004 and April 2006 (Table 2). The first harvest was $1 \mathrm{wk}$ after the last $L$. tenuis seedling record (Table 2). Biomass was classified in four groups, L. tenuis, non-legumes dicots, legumes different to L. tenuis, and monocots, which were dried (60 ${ }^{\circ} \mathrm{C}$ for $72 \mathrm{~h}$ ) and weighed afterwards. After each harvest all the paddocks were mechanically cut at $4 \mathrm{~cm}$ height and the biomass was hand removed.

Lotus tenuis plant establishment. Immediately after the last aerial biomass harvest of first and second experiment, 25 April 2006 and 13 April 2007, respectively, the number of L. tenuis adult plants was recorded in the same central subplot of each plot (Table 2, Figure 1).

\section{Second experiment}

Procedure of second experiment was done with the same methodology that in the first one. The plots were sowed on 19 April 2005 and the study finished on 13 April 2007 (Table 2). Lotus tenuis seed rain of the plants growing in the grassland was produced during reproductive season, between first and second harvest, 30 December 2004 to 31 March 2005 (indicated in Table 2 as seed rain). According to our experiments done in the same plant community, near of the paddocks, when the grazing was excluded on December at the end of reproductive period, the seed rain was approximately of $900 \mathrm{seed}^{-2}$ (Fernández et al., 2008).

\section{Climate data}

Due to the impossibility of having a meteorological station in the paddocks, precipitation data was provided by the meteorological station in Ayacucho city, distant approximately $20 \mathrm{~km}$ from experimental 
site. Evapotranspiration data (Penman-Monteith method) was proportioned by EEA-INTA Balcarce, distant at approximately $50 \mathrm{~km}$ from the paddocks. During the years 2004, 2005 and 2006 the accumulated precipitations were 931,865 and $1076 \mathrm{~mm}$, respectively. The evapotranspiration was higher than precipitation in 21 months, principally during spring and summer seasons (Figure 2).
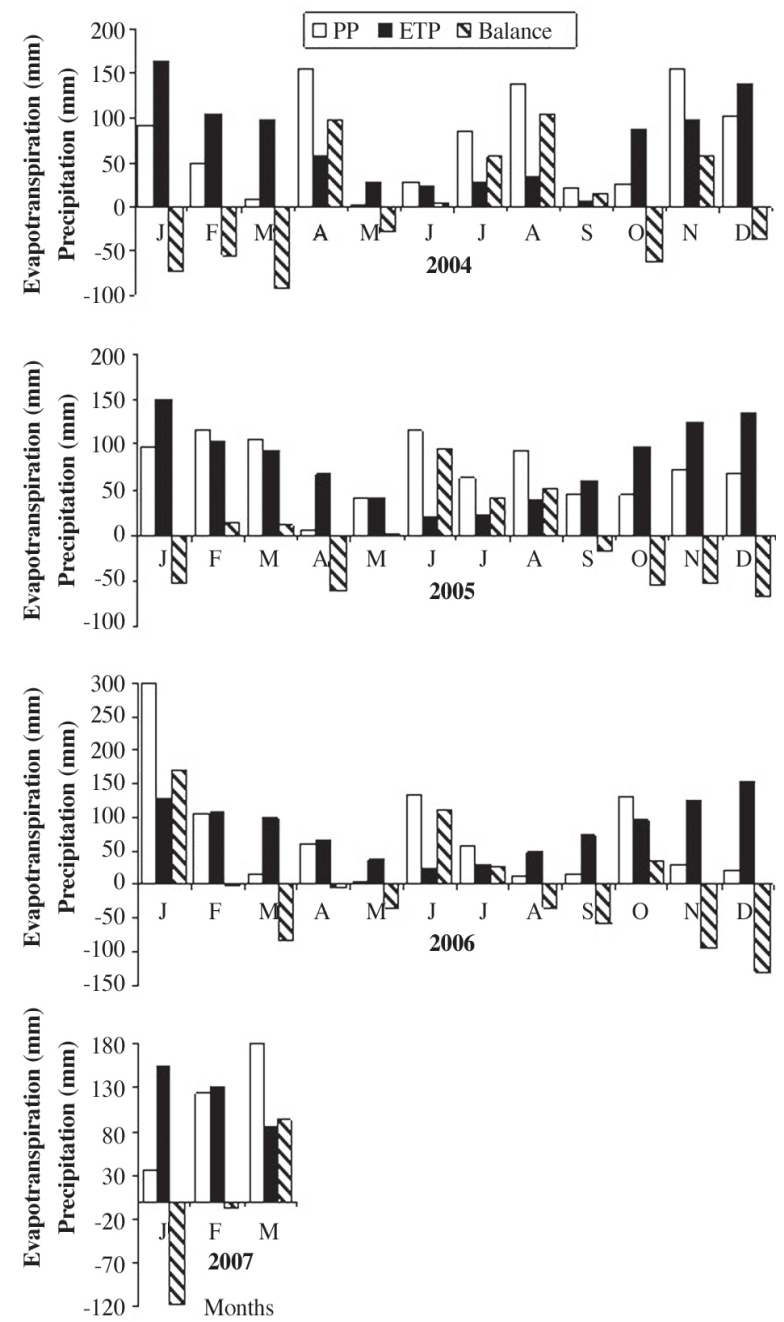

Figure 2. Precipitation (PP, mm), evapotranspiration (ETP, mm) and water balance recorded during the experimental period.

\section{Statistical analyses}

A randomized complete block design with three replicates and five seed additions as treatments were used in each paddock. Data were analyzed by ANOVA using SYSTAT procedures. Seedling density and biomass production were analyzed using a repeated-measures procedure.
Means were separated by the least significant difference test (LSD) at $\mathrm{P} \leq 0.05$. The results are presented as mean \pm standard error.

\section{RESULTS}

The biomass contribution of exotic legumes, Trifolium repens, T. fragiferum and the native Adesmia bicolour was not higher than $2.15 \mathrm{~g} \mathrm{~m}^{-2}$, approximately $0.3 \%$ respect to the total biomass production. These legumes were not present in some plots, therefore they were not considered in the calculus.

\section{Lotus tenuis seedling and plant establishment}

In both experiments, L. tenuis seedling density increased with seed addition. Seedling emergence occurred mainly in autumn and early spring and the mortality was mainly between late spring and early summer (Tables 3 and 4). Seedling number recorded in the first and second experiment varied with seed additions $(\mathrm{P} \leq 0.0001$ and $\mathrm{P} \leq$ $0.031)$, date $(\mathrm{P} \leq 0.025$ and $\mathrm{P} \leq 0.042)$ and interaction seed addition $\mathrm{x}$ date $(\mathrm{P} \leq 0.0001$ and $\mathrm{P} \leq 0.0001)$ was recorded, respectively. During both experiments $L$. tenuis clorotic seedlings were recorded.

Seedling density recorded in the last record at first period (22 December 2004) was related to seed addition:

$$
\begin{aligned}
\text { Seedling }\left(\mathrm{N}^{\circ} \mathrm{m}^{-2}\right) & =0.0925 \times \text { Seed addition }\left(\mathrm{N}^{\circ} \mathrm{m}^{-2}\right)+3.856 \\
\left(r^{2}\right. & =0.802 ; \mathrm{P} \leq 0.0001 ; \mathrm{n}=45)
\end{aligned}
$$

and seed addition more 50 seed $\mathrm{m}^{-2}$ estimated in the soil seed bank:

$$
\begin{aligned}
\text { Seedling }\left(\mathrm{N}^{\circ} \mathrm{m}^{-2}\right) & =0.0925 \times \text { Seed addition }\left(\mathrm{N}^{\circ} \mathrm{m}^{-2}\right)-0.766 \\
\left(r^{2}\right. & =0.802 ; \mathrm{P} \leq 0.0001 ; \mathrm{n}=45)
\end{aligned}
$$

Plant number established did not vary with seed additions and paddock. However, in the $4^{\text {th }}$ and $5^{\text {th }}$ seed addition plant number was higher $\left(54.44 \pm 9.14\right.$ plants $\left.\mathrm{m}^{-2}\right)$ than among $1^{\text {st }}, 2^{\text {nd }}$ and $3^{\text {rd }}$ ones $\left(31.66 \pm 4.70\right.$ plants $\left.\mathrm{m}^{-2}\right)$. Lotus tenuis seedling density in control conditions ( $1^{\text {st }}$ seed addition) of second experiment, increased approximately one hundred times (Table 4), respect to the same seed additions of first one (Table 3). This increment was attributed to seed rain. Lotus tenuis plant number established in the second experiment did not vary significantly with the seed addition and paddock, being the average $21.42 \pm 17.46$ plants $\mathrm{m}^{-2}$.

\section{Biomass production}

Total dry biomass production by plant community did not vary significantly with $L$. tenuis seed addition. Total biomass production was lower in paddock 2 (692.06 
Table 3. Lotus tenuis seedling density (mean $\pm \mathrm{SE}$ ) recorded in paddocks of a Flooding Pampa grassland during the first experiment. References: seed addition $1^{\text {st }}, 2^{\text {nd }}, 3^{\text {rd }}, 4^{\text {th }}$ and $5^{\text {th }}$.

\begin{tabular}{lccccc}
\hline & & \multicolumn{4}{c}{ Seed addition $\left(\mathbf{N}^{\mathbf{0}} \mathbf{~ m}^{-\mathbf{2}}\right)$} \\
\cline { 3 - 6 } Date & $\mathbf{1}^{\text {st }}(\mathbf{C o n t r o l})$ & $\mathbf{2}^{\text {nd }}\left(\mathbf{5 7} \mathbf{~ m}^{\mathbf{2}}\right)$ & $\mathbf{3}^{\text {rd }}\left(\mathbf{2 2 9} \mathbf{~ m}^{-\mathbf{2}}\right)$ & $\mathbf{4}^{\text {th }}\left(\mathbf{9 1 7} \mathbf{~ m}^{-\mathbf{2}}\right)$ & $\mathbf{5}^{\text {th }}\left(\mathbf{1 8 3 3} \mathbf{~ m}^{\mathbf{2}}\right)$ \\
\cline { 2 - 6 } 24 May 2004 & $2.46 \pm 0.97 \mathrm{aA}$ & $16.35 \pm 3.08 \mathrm{aAB}$ & $29.93 \pm 2.84 \mathrm{aA}$ & $144.13 \pm 19.01 \mathrm{bA}$ & $291.97 \pm 38.61 \mathrm{cBA}$ \\
1 July 2004 & $0.69 \pm 0.69 \mathrm{aA}$ & $7.63 \pm 2.50 \mathrm{aA}$ & $31.64 \pm 7.54 \mathrm{aA}$ & $212.49 \pm 29.35 \mathrm{bB}$ & $388.88 \pm 61.28 \mathrm{cBC}$ \\
27 Sept. 2004 & $4.85 \pm 2.50 \mathrm{aA}$ & $20.13 \pm 4.26 \mathrm{aB}$ & $56.24 \pm 6.75 \mathrm{aB}$ & $270.83 \pm 25.19 \mathrm{bB}$ & $459.71 \pm 67.77 \mathrm{cC}$ \\
14 Dec. 2004 & $4.08 \pm 1.96 \mathrm{aA}$ & $7.77 \pm 1.66 \mathrm{aA}$ & $25.77 \pm 5.04 \mathrm{aA}$ & $89.44 \pm 11.10 \mathrm{bA}$ & $172.88 \pm 21.85 \mathrm{cA}$ \\
\hline
\end{tabular}

Values followed by the same capital letter within columns and by the same small letter within file are not different according LSD test (P $>0.05$ ).

Table 4. Lotus tenuis seedling density (mean \pm SE) recorded in a paddock of a Flooding Pampa grassland during the second experiment. References: seed addition $1^{\text {st }}, 2^{\text {nd }}, 3^{\text {rd }}, 4^{\text {th }}$ and $5^{\text {th }}$.

\begin{tabular}{|c|c|c|c|c|c|}
\hline \multirow[b]{2}{*}{ Date } & \multirow[b]{2}{*}{$\mathbf{1}^{\text {st }}$ (Control) } & \multicolumn{4}{|c|}{ Seed addition $\left(\mathbf{N}^{0} \mathbf{m}^{-2}\right)$} \\
\hline & & $2^{\text {nd }}\left(57 \mathrm{~m}^{-2}\right)$ & $3^{\text {rd }}\left(229 \mathrm{~m}^{-2}\right)$ & $4^{\text {th }}\left(917 \mathrm{~m}^{-2}\right)$ & $5^{\text {th }}\left(1833 \mathrm{~m}^{-2}\right)$ \\
\hline & & & -Seedling $\left(\mathrm{N}^{\mathrm{o}} \mathrm{m}^{-2}\right)$ & & \\
\hline 23 June 2005 & $146.52 \pm 49.99 \mathrm{abA}$ & $104.16 \pm 19.00 \mathrm{aA}$ & $143.74 \pm 28.79 \mathrm{abA}$ & $273.58 \pm 38.56 \mathrm{abA}$ & $557.63 \pm 101.87 \mathrm{cA}$ \\
\hline 13 Sept. 2005 & $424.99 \pm 111.79 \mathrm{aB}$ & $327.77 \pm 99.67 \mathrm{aB}$ & $317.35 \pm 74.70 \mathrm{aB}$ & $379.85 \pm 84.73 \mathrm{aA}$ & $554.16 \pm 76.27 \mathrm{aA}$ \\
\hline 17 Nov. 2005 & $368.05 \pm 92.39 \mathrm{aBA}$ & $272.91 \pm 77.23 \mathrm{aBA}$ & $278.47 \pm 62.93 \mathrm{aAB}$ & $365.27 \pm 65.54 \mathrm{aA}$ & $395.13 \pm 48.81 \mathrm{aA}$ \\
\hline
\end{tabular}

Values followed by the same capital letter within columns and by the same small letter within file are not different according LSD test $(\mathrm{P}>0.05)$.

\pm 37.38 and $\left.589.94 \pm 26.89 \mathrm{~g} \mathrm{~m}^{-2} \mathrm{yr}^{-1}\right)$ than in paddock $1\left(995.96 \pm 33.42\right.$ and $\left.953.07 \pm 55.80 \mathrm{~g} \mathrm{~m}^{-2} \mathrm{yr}^{-1}\right)$ and $3\left(1042.44 \pm 54.39\right.$ and $\left.743.77 \pm 46.69 \mathrm{~g} \mathrm{~m}^{-2} \mathrm{yr}^{-1}\right)$, by the first and second experiment, respectively. In average monocots, dicots non legume and L. tenuis biomass contribution was approximately 80,10 and $10 \%$, respectively.

In the first experiment, L. tenuis biomass production varied with the seed addition $(\mathrm{P} \leq 0.002)$ and paddock $(\mathrm{P}$ $\leq 0.004$ ) (Table 5). Lotus tenuis total biomass production by the $4^{\text {th }}$ and $5^{\text {th }}$ seed addition $\left(109.51 \pm 30.68 \mathrm{~g} \mathrm{~m}^{-2}\right)$ was significantly higher $(\mathrm{P} \leq 0.026)$ than the $1^{\text {st }}, 2^{\text {nd }}$ and $3^{\text {rd }}$ addition $\left(42.73 \pm 8.40 \mathrm{~g} \mathrm{~m}^{-2}\right)$. Lotus tenuis total biomass production was related to seedling number recorded in the last record of (22 December 2004):
Biomass $\left(\mathrm{g} \mathrm{m}^{-2}\right)=0.445 \times$ Seedling $\left(\mathrm{N}^{\circ} \mathrm{m}^{-2}\right)+42.987$

$$
\left(r^{2}=0.190 ; \mathrm{P} \leq 0.003 ; \mathrm{n}=45\right)
$$

In the second experiment, L. tenuis total biomass production varied with date $(\mathrm{P}<0.02)$. Except in the last record, biomass production did not vary with seed addition, being in average $73.40 \pm 9.68 \mathrm{~g} \mathrm{~m}^{-2}$ (Table 6).

\section{Climate data}

During years 2004, 2005 and 2006 the accumulated precipitations were of 931,865 and $1076 \mathrm{~mm}$, respectively. During the experimental period 21 months were recorded with negative water balance. The more affected months corresponded to spring and summer seasons (Figure 2).=

Table 5. Lotus tenuis biomass (mean \pm SE) recorded in a paddock of a Flooding Pampa grassland during the first experimental period. References: seed addition $1^{\text {st }}, 2^{\text {nd }}, 3^{\text {rd }}, 4^{\text {th }}$ and $5^{\text {th }}$.

\begin{tabular}{|c|c|c|c|c|c|}
\hline \multirow[b]{2}{*}{ Date } & \multirow[b]{2}{*}{$1^{\text {st }}$ (Control) } & \multicolumn{4}{|c|}{ Seed addition $\left(\mathrm{N}^{0} \mathrm{~m}^{-2}\right)$} \\
\hline & & $2^{\text {nd }}\left(57 \mathrm{~m}^{-2}\right)$ & $3^{\text {rd }}\left(229 \mathrm{~m}^{-2}\right)$ & $4^{\text {th }}\left(917 \mathrm{~m}^{-2}\right)$ & $5^{\text {th }}\left(1833 \mathrm{~m}^{-2}\right)$ \\
\hline & & ( & Biomass $\left(\mathrm{g} \mathrm{m}^{-}\right.$ & & \\
\hline 30 Dec. 2005 & $12.22 \pm 4.55 \mathrm{a}$ & $8.38 \pm 3.71 \mathrm{a}$ & $14.83 \pm 3.27 \mathrm{ab}$ & $11.91 \pm 3.62 \mathrm{a}$ & $30.85 \pm 11.40 b$ \\
\hline 31 May 2005 & $15.02 \pm 5.63 \mathrm{a}$ & $6.80 \pm 2.52 \mathrm{a}$ & $7.33 \pm 2.10 \mathrm{a}$ & $14.36 \pm 5.40 \mathrm{a}$ & $31.20 \pm 9.26 b$ \\
\hline 1 Dec. 2005 & $4.72 \pm 1.53 \mathrm{a}$ & $11.06 \pm 4.54 \mathrm{ab}$ & $11.11 \pm 5.94 \mathrm{ab}$ & $34.27 \pm 16.42 b c$ & $40.75 \pm 13.61 c$ \\
\hline 25 April 2006 & $13.95 \pm 7.69 b$ & $6.66 \pm 2.04 \mathrm{a}$ & $16.08 \pm 4.82 \mathrm{a}$ & $30.44 \pm 13.08 \mathrm{ab}$ & $25.24 \pm 5.35 \mathrm{ab}$ \\
\hline
\end{tabular}

Values followed by the same small letter within file are not significantly different according LSD test $(\mathrm{P}>0.05)$. 
Table 6. Lotus tenuis biomass (mean \pm SE) recorded in paddocks of a Flooding Pampa grassland during the second experimental period. References: seed addition $1^{\text {st }}, 2^{\text {nd }}, 3^{\text {rd }}, 4^{\text {th }}$ and $5^{\text {th }}$.

\begin{tabular}{lccccc}
\hline & & \multicolumn{4}{c}{ Seed addition $\left.\mathbf{( N}^{\mathbf{0}} \mathbf{~}^{-\mathbf{2}}\right)$} \\
\cline { 3 - 6 } Date & $\mathbf{1}^{\text {st }}($ Control $)$ & $\mathbf{2}^{\text {nd }}\left(\mathbf{5 7} \mathbf{~ m}^{-\mathbf{2}}\right)$ & $\mathbf{3}^{\text {rd }}\left(\mathbf{2 2 9} \mathbf{~ m}^{-\mathbf{2}}\right)$ & $\left.\mathbf{4}^{\text {th }} \mathbf{( 9 1 7} \mathbf{~ m}^{-\mathbf{2}}\right)$ & $\left.\mathbf{5}^{\text {th }} \mathbf{( 1 8 3 3} \mathbf{~ m}^{-\mathbf{2}}\right)$ \\
\cline { 2 - 5 } 30 Nov. 2005 & $4.89 \pm 1.37 \mathrm{aA}$ & $5.77 \pm 1.88 \mathrm{aA}$ & $5.41 \pm 2.21 \mathrm{aA}$ & $6.02 \pm 1.23 \mathrm{aA}$ & $6.45 \pm 1.31 \mathrm{aA}$ \\
11 April 2006 & $13.91 \pm 4.24 \mathrm{aAB}$ & $16.84 \pm 7.22 \mathrm{aAB}$ & $17.06 \pm 5.07 \mathrm{aA}$ & $19.28 \pm 5.16 \mathrm{aAB}$ & $24.00 \pm 8.75 \mathrm{aAB}$ \\
15 Dec. 2006 & $19.83 \pm 7.40 \mathrm{aB}$ & $36.69 \pm 15.25 \mathrm{aB}$ & $20.44 \pm 7.95 \mathrm{aA}$ & $21.57 \pm 6.15 \mathrm{aAB}$ & $27.47 \pm 8.97 \mathrm{aAB}$ \\
13 April 2007 & $9.52 \pm 2.93 \mathrm{aAB}$ & $24.49 \pm 9.00 \mathrm{abAB}$ & $19.55 \pm 5.27 \mathrm{abA}$ & $25.51 \pm 10.61 \mathrm{abB}$ & $42.21 \pm 14.81 \mathrm{bB}$ \\
\hline
\end{tabular}

Values followed by the same capital letter within columns and by the same small letter within file are not significantly different according LSD test (P $>0.05$ )

\section{DISCUSSION}

In the first period seed addition explained the $81 \%$ and $19 \%$ of the variation in seedling density and L. tenuis biomass, respectively. Lotus tenuis response to seed addition could have been conditioned by its grazing history and climate variables, for example, precipitations. Under continuous grazing the removal of reproductive and vegetative organs of $L$. tenuis can negatively affect the seed production and consequently the soil seed bank size (Bologna et al., 1996; Sternberg et al., 2003; Fernández et al., 2008). Lotus tenuis soil seed bank recorded in the same grassland, near of the paddocks, was estimated in approximately $50 \mathrm{seed} \mathrm{m}^{-2}$ (Fernández et al., 2008). Therefore, the increment of L. tenuis seedling with the seed additions could be in response to the low soil seed bank. In the second experiment, L. tenuis seed rain produced during the period 30 December 2004 to 31 March 2005 increased the soil seed bank and determining little differences in seedling density between control and $2^{\text {nd }}$ and $3^{\text {rd }}$ seed addition.

Favorable conditions for L. tenuis seedling emergence was in spring, as well as it was reported by Sevilla et al. (1996) in a pasture composed by Festuca arundinacea Schreb. Lotus tenuis seedling mortality was important in this experiment, being consistent with the reports about its low implantation efficiency, considered as seedling established respect to seed sowed. Implantation efficiency of L. tenuis in the Flooding Pampa grasslands and pastures were recorded between 9.5 and $0.1 \%$ (Miñón y Colabelli, 1993). Lotus tenuis seedling mortality by different environmental factors as fungal (Juan et al., 2000), seed predation by rodents, failure of some seedling to penetrate the soil surface and summer water deficit (Colabelli and Miñón, 1993; Wilsey and Polley, 2003; Lenz and Facelli, 2005) and plant competition (Sevilla et al., 1996) are some factors that can explain the decrease of seedling number in the experiments.

Lotus tenuis seedling started to die off as soon as plant communities began to regrow. Lotus tenuis seeds are small (approximately $1 \mathrm{mg}$ ) and the seedling with poor vigour. Seedling recruitment and survival are dependent on open gaps or low plant competition (Colabelli and Miñón, 1993; Miñón and Colabelli, 1993; Sevilla et al., 1996; Laterra, 1997; Juan et al., 2000). Low seedling density in early summer reflects the high mortality risks in this season. Water availability during summer in the Flooding Pampa grasslands, appears to be an important environmental factor controlling L. tenuis plant survival and biomass production (Colabelli and Miñón, 1993; Vignolio et al., 2010). Oesterheld and León (1987) did not find differences in biomass production in pastures of 2, 5 and $13 \mathrm{yr}$ old growing in the Flooding Pampa. The hypothesis proposed by these authors and others (Costa and García, 1997; Fernández Grecco, 2001) was that soil fertility and water would be the decisive factors determining the biomass production of the grasslands. This appreciation agrees with the results of Wilsey and Polley (2003) who added seeds of 20 species -perennial $\mathrm{C}_{4}$ and $\mathrm{C}_{3}$ grasses, legumes and forbs- in subhumid grassland of Texas, USA. In hot and dried summers, water availability was an important factor controlling seedling establishment and biomass production (Wilsey and Polley, 2003). Flooding Pampa grasslands, can remain exposed to temporary summer drought and available water can be an abiotic key element to the survival and biomass production of these grasslands (Wilsey and Polley, 2003; Lenz and Facelli, 2005; Thomsen et al., 2006). The lower biomass production of the plant community (average of the three paddocks) in the second experiment $\left(762 \mathrm{~g} \mathrm{~m}^{-2} \mathrm{yr}^{-1}\right)$ respect to the first one $\left(910 \mathrm{~g} \mathrm{~m}^{-2} \mathrm{yr}^{-1}\right)$ can be attributed to the scarce precipitations during November and December 2006. Total biomass produced by plant community was not significantly increased through $L$. tenuis seed additions and seed rain. However, L. tenuis biomass contribution is important in the Flooding Pampa grasslands rich in grass species, poor in native legume and in soil $\mathrm{N}$ (Colabelli and Viviani Rossi, 1997; Costa and García, 1997; Fernández Grecco, 2001). 


\section{Management implications}

In the Flooding Pampa grasslands the growth of native legumes and their biomass production were insignificant respect to Lotus tenuis, which is an economically important species of these grasslands. Plant communities containing L. tenuis are generally heavily grazed, indicating a higher palatability and forage quality, but affecting negatively the seed production (Fernández et al., 2008). Fluctuations in propagule availability can play an important role in the L. tenuis seedling recruitment and biomass production in the grasslands.

\section{CONCLUSIONS}

Our results provide preliminary information about management of $L$. tenuis in these grasslands to reduce the declination of its plant stand and biomass production. Seedlings, plant establishment and biomass productivity can be increased through seed addition and/or natural reseeding. Natural reseeding can be reached by increasing the soil seed bank size through grazing exclusion during L. tenuis reproductive period.

\section{ACKNOWLEDGEMENTS}

We thank María Rosa Desirello, Sara Garfinkel and referees for critical reading of the text. This research was supported by the Universidad Nacional de Mar del Plata.

\section{RESUMEN}

Establecimiento de plántulas y producción de biomasa de Lotus tenuis en pastizales de la Pampa Deprimida (Buenos Aires, Argentina). En pastizales y pasturas ha sido documentada la reducción de la densidad de plantas y de la biomasa de Lotus tenuis Waldst. \& Kit. ex Willd. Nuestro objetivo fue determinar si su densidad de plantas y su producción de biomasa pueden ser incrementadas en un pastizal mediante la adición de semillas. Dos experimentos sin pastoreo fueron realizados en tres potreros de un pastizal de la Pampa Deprimida. El primer experimento fue realizado entre otoño 2004-otoño 2006 y el segundo entre otoño 2005-otoño 2007. Diferentes cantidades de semillas (0, 57, 229, 917 y 1833 semillas $\mathrm{m}^{-2}$ ) fueron esparcidas a mano en las parcelas experimentales. En el segundo experimento, además de la adición de semillas, también se produjo la siembra de aproximadamente 900 semillas $\mathrm{m}^{-2}$, por los aportes de las plantas de L. tenuis del pastizal. La densidad de semillas explicó el $81 \%$ y el 19\% de la variación de la densidad de plántulas y la producción de biomasa de L. tenuis, respectivamente.
La emergencia de plántulas fue principalmente entre otoño-principios de primavera y la mortalidad entre primavera tardía-verano. La densidad de plantas adultas y la biomasa producida por L. tenuis se incrementaron con la adición de semillas. La biomasa total del pastizal varió entre $589,94 \pm 26,89$ y $1042,44 \pm 54,39 \mathrm{~g} \mathrm{~m}^{-2}$ $\mathrm{año}^{-1} \mathrm{y}$ las diferencias fueron atribuidas principalmente a las precipitaciones. La contribución de L. tenuis fue del $10 \%$. Los resultados sugieren que el establecimiento de plántulas, de plantas y la producción de biomasa de L. tenuis pueden aumentar en el pastizal por la adición de semillas y/o por la lluvia de semillas mediante la exclusión del pastoreo durante el período reproductivo.

Palabras clave: leguminosa, calidad forrajera, atributos poblacionales, mortalidad de plántulas, adición de semillas.

\section{LITERATURE CITED}

Acuña, H.P., y G. Cuevas. 1999. Efecto de la altura y frecuencia de la defoliación, bajo corte y pastoreo, en el crecimiento y productividad de tres especies del género Lotus en suelos arcillosos. Agricultura Técnica 59:296-308.

Bologna, J.J., J.S. Rowarth, T.J. Fraser, and G.D. Hill. 1996. Management of birdsfoot trefoil (Lotus corniculatus L.) pastures for productivity and persistence. Proceedings of the Agronomy Society of New Zealand 26:17-21.

Colabelli, M.R., y D.P. Miñón. 1993. Métodos de intersiembra de Lotus tenuis y Trifolium repens en pastizales de la Pampa Deprimida bonaerense. Revista Argentina Producción Animal 13:225-233.

Colabelli, M.R., y D.P. Miñón. 1994. Rendimiento y cambios botánicos de pasturas de Lotus tenuis puro y en mezcla bajo régimen de corte. Agricultura Técnica 54:39-45.

Colabelli, M., y E.M. Viviani Rossi. 1997. Efecto de dos métodos de intersiembra de Lotus tenuis sobre su implantación y sobre la producción de forraje de pastizales del área ganadera del salado (Argentina). Avances en Producción Animal 22:123-128.

Costa, J.L., y F.O. García. 1997. Respuesta de un pastizal natural a la fertilización con fósforo y nitrógeno en un Natracuol. Revista de Investigaciones Agropecuarias 28:31-39.

Fernández Grecco, R. 2001. Efecto de la fertilización nitrogenada invernal sobre la acumulación de forraje de un pastizal natural de la Pampa Deprimida, Argentina. Agricultura Técnica 61:319325. 
Fernández, O.N., O.R. Vignolio, y G.S. Cambareri. 2008. Persistencia de Lotus tenuis bajo pastoreo por vacunos: períodos críticos para la supervivencia y la reproducción. p. 34-35. In Ruiz, O. (ed.) IV Taller Interdisciplinario de Lotus: Aspectos Genéticos, Moleculares y Ecofisiológicos de Lotus spp. y sus Simbiontes, Chascomús. Noviembre 2008. IIB-INTECH, CONICET, UNSAM, Buenos Aires, Argentina.

Juan, V.F., L. Monterroso, M.B. Sacido, and M.A. Cauhépé. 2000. Postburning legume seedling in the Flooding Pampas, Argentina. Journal of Range Management 53:300-304.

Laterra, P. 1997. Post-burn recovery in the flooding Pampa: Impact of an invasive legume. Journal of Range Management 50:274-277.

Lenz, T.I., and J.M. Facelli. 2005. The role of seed limitation and resource availability in the recruitment of native perennial grasses and exotics in a South Australian grassland. Austral Ecology 30:684-694.

Martin, L.M., and B.J. Wilsey. 2006. Assessing grassland restoration success: relative roles of seed additions and native ungulate activities. Journal of Applied Ecology 43:1098-1109.

Miñón, D.P., y M.R. Colabelli. 1993. Intersiembra de Lotus tenuis en tres comunidades nativas de la Pampa Deprimida. Revista Argentina de Producción Animal 13:133-140.

Miñón, D.P., y R.O. Refi. 1993. Persistencia de pasturas de Festuca arundinacea, Trifolium repens y Lotus tenuis bajo pastoreo continuo. Diálogo 38. p. 95-102. Metodología de Evaluación de Pasturas.

Oesterheld, M., y R.J. León. 1987. El envejecimiento de las pasturas implantadas: su efecto sobre la productividad primaria. Turrialba 37:29-35.

Oesterheld. M., and O.E. Sala. 1990. Effects of grazing on seedling establishment: the role of seed and safe-site availability. Journal of Vegetation Science 1:353-358.

Quinos, P.M., P. Insausti, and A. Soriano. 1998. Facilitative effect of Lotus tenuis and Paspalum dilatatum in a lowland grassland of Argentina. Oecologia 114:427431.
Refi, R.O., and C.J. Escuder. 1998. Nitrogen fixation by Trifolium repens and Lotus tenuis-based pastures in the Flooding Pampa, Argentina. Agronomie 18:285297.

Sevilla, G.H., O.N. Fernández, D.P. Miñón, and L. Montes. 1996. Emergence and seedling survival of Lotus tenuis in Festuca arundinacea pastures. Journal of Range Management 49:509-511.

Sternberg, M., M. Gutman, A. Perevolotsky, and J. Kigel. 2003. Effects of grazing on soil seed bank dynamics: An approach with functional groups. Journal of Vegetation Science 14:375-386.

Thomsen, M.A., C.M. D'Antonio, K.B. Suttle, and W.P. Sousa. 2006. Ecological resistance, seed density and their interactions determine patterns of invasion in a California coastal grassland. Ecology Letters 9:160170.

Tilman, D. 1997. Community invisibility, recruitment limitation, and grassland biodiversity. Ecology 78:8192.

Vignolio, O.R., G.S. Cambareri, y N.O. Maceira. 2010. Lotus tenuis (Fabaceae). Producción y manejo agronómico. Revista Argentina de Producción Animal 30:97-116.

Vignolio, O.R., and O.R. Fernández. 2010. Cattle dung as vector of spreading seeds of exotic species in the Flooding Pampa grasslands (Buenos Aires, Argentina). Annales Botanici Fennici 47:14-22.

Vignolio, O.R., O.N. Fernández, and N.O. Maceira. 1999. Flooding tolerance in five populations of Lotus glaber Mill. (Syn. Lotus tenuis Waldst. et Kit.). Australian Journal of Agricultural Research 50:555-559.

Wilsey, B.J., and H.W. Polley. 2003. Effects of seed additions and grazing history on diversity and productivity of subhumid grasslands. Ecology 84:920931.

Zobel, M., M. Otsus, J. Liira, M. Moora, and T. Möls. 2000. Is small-scale species richness limited by seed availability or microsite availability? Ecology 81:3274-3282. 